Ann. Acad. Med. Siles. (online) 2015; 69: 41-48

\title{
Serum concentration of copeptin in newborns with congenital heart defect
}

\section{Stężenie kopeptyny w surowicy noworodków z wrodzoną wadą serca}

\author{
Anna Tarko1,2 (D) , Anna Suchojad1,2 (D) , Julia Kordyś1 ${ }^{1}$ Svetlana Simonova1', Iwona Maruniak-Chudek1,2 (iD)
}

${ }^{1}$ Oddział Neonatologii, Patologii i Intensywnej Terapii Noworodka, Górnoślaskie Centrum Zdrowia Dziecka

im. św. Jana Pawła II, Samodzielny Publiczny Szpital Kliniczny nr 6 Śląskiego Uniwersytetu Medycznego w Katowicach

2Klinika Neonatologii, Patologii i Intensywnej Terapii Noworodka, Wydział Nauk Medycznych w Katowicach, Śląski Uniwersytet Medyczny w Katowicach

\section{ABSTRACT}

INTRODUCTION: Neonates with congenital heart defects (CHD) require careful fluid management due to the risk of cardiovascular failure. Routine laboratory parameters are not the optimal tool to detect fluid overload; therefore the search for novel markers is justified. Copeptin (pre-pro-vasopressin - CTproAVP) may be one of them. The aim of the study was to analyze the influence of the current protocol of hydration in neonates with CHD on the physiological volume homeostasis measured with CTproAVP.

MATERIAL AND METHODS: Ten term newborns with CHD hospitalized in neonatal intensive care before cardiac surgery were enrolled in the study. Four of them presented symptoms of respiratory insufficiency and all except two received alprostadil. Clinical management was routine, with the exception of CTproAVP measurement in the first five days of life with evaluation of serum and urine osmolality. Fluid intake was within the normal range for age. Term, healthy neonates $(\mathrm{N}=200)$ served as the control.

RESULTS: The current hydration protocol did not cause an increase in serum and urine osmolality compared to the controls. The effective osmolality of the analyzed body fluids was even lower in the neonates with CHD. The concentration of CTproAVP was also lower in the study group, but the difference was not statistically significant. There were no clinical signs of cardiovascular distress or overhydration. No factors explaining the variability in CTproAVP concentration were identified.

CONCLUSIONS: These preliminary data suggest that the protocol of hydration does not cause dehydration or stimulation of CTproAVP release. It seems that even more restrictive protocols of fluid management can be applied in newborns with CHD at the risk of pulmonary congestion. A longer observation period is needed, including the postoperative period, to obtain more reliable information on optimal fluid management and the role of CTproAVP in monitoring volemia.

KEY WORDS

congenital heart defect, hydration status, newborn, copeptin, effective serum osmolality

\footnotetext{
Received: 19.03 .2020

Revised: 16.04 .2020

Accepted: 01.01.2021

Published online: 26.05 .2021

Address for correspondence: prof. dr hab. n. med. i n. o zdr. Iwona Maruniak-Chudek, Klinika Neonatologii, Patologii i Intensywnej Terapii Noworodka, Wydział Nauk Medycznych w Katowicach, Ślaski Uniwersytet Medyczny w Katowicach, ul. Medyków 16, 40-752 Katowice, tel. +48 322071780 , e-mail: ichudek@sum.edu.pl
}

Copyright @ Śląski Uniwersytet Medyczny w Katowicach

www.annales.sum.edu.pl 


\section{STRESZCZENIE}

WSTĘP: Noworodki z wrodzoną wadą serca (WWS) wymagają ostrożnej terapii płynami z uwagi na ryzyko wystąpienia niewydolności krążenia. Rutynowe badania laboratoryjne nie są optymalnym narzędziem w identyfikacji stanu przewodnienia i dlatego konieczne są poszukiwania nowych markerów. Kopeptyna (CTproAVP) może być jednym z nich. Celem pracy była analiza wpływu aktualnie obowiązującego protokołu nawadniania noworodków z WWS na homeostazę wolemii z wykorzystaniem CTproAVP.

MATERIAŁ I METODY: Do badania włączono 10 noworodków z WWS hospitalizowanych na oddziale intensywnej terapii noworodka przed zabiegiem kardiochirurgicznym. Cztery z nich prezentowały objawy niewydolności oddechowej, a wszystkie z wyjątkiem dwóch otrzymywały alprostadil. Postępowanie kliniczne było rutynowe, z wyjątkiem pomiaru CTproAVP w pierwszych pięciu dniach życia wraz z oceną osmolalności surowicy i moczu. Podaż płynów mieściła się w zakresach normy dla wieku. Grupę kontrolną stanowiło 200 zdrowych donoszonych noworodków.

WYNIKI: Aktualny protokół nawadniania nie powodował, w porównaniu z grupą kontrolną, wzrostu stężenia osmolalności surowicy i moczu. Efektywna osmolalność analizowanych płynów ustrojowych była nawet niższa u noworodków z WWS. Również stężenie CTproAVP było niższe w grupie badanej, lecz różnica nie była istotna statystycznie. Nie obserwowano klinicznych objawów niewydolności krążenia lub przewodnienia. Nie zidentyfikowano czynników, które wyjaśniałyby zmienność w stężeniu CTproAVP.

WNIOSKI: Wstępne wyniki sugerują, że aktualny protokół nawadniania nie powoduje odwodnienia ani nie stymuluje uwalniania CTproAVP. Wydaje się, że u noworodków z WWS i ryzykiem przeciążenia krążenia płucnego można zastosować nawet bardziej restrykcyjny protokół nawadniania. Konieczna jest dłuższa obserwacja, z włączeniem okresu pooperacyjnego, aby otrzymać bardziej miarodajne dane na temat optymalnego nawodnienia i roli kopeptyny w monitorowaniu wolemii.

SŁOWA KLUCZOWE

wrodzona wada serca, stan nawodnienia, noworodek, kopeptyna, efektywna osmolalność surowicy

\section{INTRODUCTION}

Hydration is an essential process to maintain the homeostasis of body water and electrolytes. The interplay of several hormones e.g. arginine vasopressin (AVP), natriuretic peptides, and the renin-angiotensin-aldosterone system ensures proper regulation of fluid intake and output, as well as protects healthy individuals against dehydration or fluid overload.

In numerous clinical conditions, water balance is maintained by the infusion of a certain amount of different fluids, including nutritional substances and medications, while the output is stimulated by diuretics. In these cases, the interference in body homeostasis requires monitoring of the water balance and is supported by calculations of fluid requirement based on clinical data.

Hypothetically, monitoring the changes in AVP may help to improve fluid balance management. Unfortunately, this substance is not a very grateful marker due to its instability and short lifetime [1]. Human pre-pro-vasopressin (1-164), known as copeptin (CTproAVP), is supposed to be more useful in laboratory measurements [2]. For the first time since it was mentioned more than forty years ago, but described precisely only in $2005[3,4]$, CTproAVP seemed to be a better indicator of hydration, and analysis of its concentrations in various disease states was started. However, the obtained results indicated that CTproAVP concentration is also influenced by other factors besides hydration, like stress, circulatory insufficiency, hypoxia or sepsis [4,5,6,7].

Some researchers have studied the role of CTproAVP in evaluating circulatory status in pathological conditions in adults, mainly in post-cardio surgery evaluation $[8,9]$. CTproAVP in patients with various cardiovascular pathologies, including left heart failure was shown to be linked with higher mortality $[1,10,11]$.

Neonates with congenital heart defects (CHD) constitute a very special group of patients with cardiovascular pathology. While in the adaptation period to extrauterine life, at the same time they experience the effects of abnormal circulation. Such patients' fluids should be managed carefully due to the risk of pulmonary congestion. To protect the cardiovascular system against overload, moderate to restrictive fluid therapy and echocardiography (ECHO) evaluation are usually recommended and prescribed.

The available routine laboratory parameters are not very useful to detect fluid overload. This makes the optimal fluid intake remain elusive and justifies the search for novel markers that enable fluid therapy with a minimized risk of overload.

The study aimed to analyze the influence of the unit's current protocol of fluid management in neonates with CHD on the physiological volume homeostasis measured with CTproAVP. 


\section{MATERIAL AND METHODS}

The study included 10 neonates with CHD hospitalized in the Intensive Care and Neonatal Pathology Unit (neonatal intensive care unit - NICU) before cardiac surgery. All of them were born at term, without any signs or symptoms of perinatal distress and were suspected of heart malformation based on the prenatal evaluation, which was confirmed after delivery. Six patients were born by caesarean section and four by vaginal delivery. There was usually more than one cardiac pathology and a list of them is presented in Table I. The newborns were born in other perinatal units and transferred to our NICU by a neonatal emergency transport team in the first two days of life. According to the accepted unit protocol, the patients were placed under a radiant warmer and underwent clinical evaluation, including physical examination, cardiologic examination with ECHO, head and abdominal ultrasonography and laboratory tests. Biophysical monitoring of the basic parameters was introduced and the newborns were cared for and observed by NICU staff on a 24-hour basis. The clinical condition was estimated using the Neonatal Therapeutic Intervention Scoring System (NTISS) once a day, to objectify the assessment. Four of them presented symptoms of respiratory insufficiency and all except two received alprostadil (Prostin VR, prostaglandin E2).

\begin{tabular}{|c|c|c|c|c|}
\hline Case & Cardiac defect & $\begin{array}{c}\text { Prostin VR } \\
\text { (alprostadil) }\end{array}$ & $\begin{array}{l}\text { Cardiovascular } \\
\text { status }\end{array}$ & Respiratory status \\
\hline No 1 & $\begin{array}{l}\text { VSD with left to right shunt (hemodynamically } \\
\text { significant), ASD II, HP }\end{array}$ & no & efficient & $\begin{array}{l}\text { moderate insufficiency (congenital } \\
\text { pneumonia) } \\
\text { respiratory support: nCPAP }\end{array}$ \\
\hline No 2 & TGA, VSD, PFo, PDA & yes & efficient & $\begin{array}{l}\text { moderate insufficiency } \\
\text { respiratory support: oxygen by nasal cannula }\end{array}$ \\
\hline No 3 & dTGA, PFo, PDA & yes & efficient & $\begin{array}{l}\text { insufficiency } \\
\text { respiratory support: mechanical ventilation }\end{array}$ \\
\hline No 4 & AS, DILV, TS, CoA & yes & efficient & efficient \\
\hline No 5 & $\begin{array}{l}\text { IAA type B, hypoplastic aortic valve and } \\
\text { ascending part of Ao, VSD, PDA }\end{array}$ & yes & efficient & efficient \\
\hline No 6 & $\| A / t i g h t$ CoA, AS, VSD, ASD ॥/PFo & yes & efficient & efficient \\
\hline No 7 & dTGA, CoA, AS VSD, ASD, PDA & yes & efficient & efficient \\
\hline No 8 & $\begin{array}{l}\text { dTGA, VSD, ASD II/PFo, PDA, lower range of } \\
\text { left ventricle dimensions }\end{array}$ & yes & efficient & $\begin{array}{l}\text { moderate insufficiency } \\
\text { respiratory support: oxygen by nasal cannula }\end{array}$ \\
\hline No 9 & PA+IVS HRHS, PDA, PFo/ASD ॥ & yes & efficient & efficient \\
\hline No 10 & VSD & no & efficient & efficient \\
\hline
\end{tabular}

Ao - Aorta, AS - aortic stenosis, ASD - atrial septal defect, ASD II - atrial septal defect type II, CoA - coarctation of aorta, DILV - double inlet left ventricle, dTGA - dextro-transposition of the great arteries, HP - pulmonary hypertension, HRHS - hypoplastic right heart syndrome, IAA - interrupted aortic arch, nCPAP - nasal continuous positive airway pressure, PA+IVS - pulmonary atresia with intact ventricular septum, PDA - persistent ductus arteriosus, PFo persistent foramen ovale, TS - tricuspid stenosis, VSD - ventricular septal defect

The protocol enabled close monitoring and was a part of the preparation for cardiac surgery. Nevertheless, in the same way, the newborn was separated from its mother with all the consequences of this situation. Even though the mothers were encouraged to supply their children with breast milk, still, the separation was not a positive factor for stimulating lactation. Feeding was based on the provided mother's milk or milk formula given by bottle or gastric tube if the newborn presented any symptoms of fatigue caused by suckling. An additional amount of fluid was given with the intravenous infusion of alprostadil, usually at the rate of $1 \mathrm{ml}$ per hour. During the observational period, the patients were monitored to evaluate their cardiorespiratory efficiency, acid-base status and biochemical parameters (glucose, lactates, bilirubin), markers of infection, and a urine test. The serum samples remaining after those tests were used to perform copeptin evaluation, urine osmolality as well as to calculate the effective serum osmolality. The first evaluation was performed on the second or third day of life, and also on further days $\left(4^{\text {th }}\right.$ $\left.-5^{\text {th }}\right)$ if a blood sample was collected for clinical reasons.

Two hundred term neonates hospitalized in a regular nursery served as the control. Blood samples in the healthy population were collected after 48 hours of life when routine screening tests were performed. CTproAVP evaluation was performed based on a separate study protocol with the aim to compare the CTproAVP concentration with ultrasound measure- 
ment of the diameter of the great vessels. The newborns in the control group were checked for brain or abdominal pathology by point of care ultrasonography visualization and enrolled only if the examination did not reveal any abnormality. The project was evaluated and accepted by the Bioethics Committee of the Medical University of Silesia and registered with the number KNW/0022/KB1/81/I/13. The newborns were enrolled in the study when their parents or legal guardians signed the formal consent. Participation in the observation did not influence the treatment protocol.

The blood collected for copeptin evaluation (up to $500 \mu \mathrm{L}$ ) was centrifuged, then the drawn serum was transferred to Eppendorf vials and stored frozen in $-70^{\circ} \mathrm{C}$ up to 2 years. The CTproAVP concentrations were measured using the ELISA kit from USCN (Wuhan, China) with the intra-assay coefficient of variation $<10 \%$, and the inter-assay coefficient of variation $<12 \%$. Urine samples were collected when urinalysis was performed. Urine osmolality (UO) was determined by measuring the freezing point depression. Serum effective osmolarity was calculated using the formula: 2 x serum sodium concentration $(\mathrm{mM} / \mathrm{L})+$ serum glucose concentration $(\mathrm{mM} / \mathrm{L})$ - all the needed values were obtained from routine lab tests.

Cardiology monitoring included physical examination, evaluation of the biophysical parameters (heart rate HR, blood pressure - BP, capillary refill time - CRT, hemoglobin saturation with oxygen $-\mathrm{SatO}_{2}$, diuresis, fluid balance) and ECHO with routine measurements and calculations, in addition to Doppler imaging.

\section{Statistical analysis}

Statistical analyses were performed using the STATISTICA 13.0 PL for Windows software package (StatSoft Tulsa, OK, U.S.). The values are presented as means with $95 \%$ confidence intervals or medians with the interquartile range, as appropriate. To compare the groups, Pearson's chi-squared test (qualitative variables) and Student's t-test or the Mann-Whitney U test (quantitative variables) were used.

In all the statistical tests, $p$ values below 0.05 were considered statistically significant.

\section{RESULTS}

The study population did not differ statistically from the control group in gender distribution, mode of delivery or gestational age. The newborns with CHD presented a lower birth weight and 5-minute Apgar score, but still within the normal range of a good and stable clinical condition. The basic laboratory evaluation revealed the hematocrit, serum creatinine, glucose and sodium as normal values. The $\mathrm{C}$-reactive protein (CRP) concentration was low, not indicating any significant inflammatory status.

All except two patients were given alprostadil (prostaglandin E2). In four newborns there was a need for respiratory support. One patient presented symptoms of intrauterine infection and pneumonia and was given nCPAP (nasal continuous positive airway pressure) with quick improvement. Another patient presented symptoms of respiratory insufficiency in the form of frequent episodes of apnea, caused probably by alprostadil. The newborn was supported by intubation and mechanical ventilation changed very soon to nCPAP. The last two patients needed some oxygen provided by nasal cannula, and that moderate respiratory insufficiency was caused by an undefined perinatal infection. Except for one patient who needed respiratory support for apnea, there were no side effects of prostaglandin E2 observed in the study population.

\section{Fluid therapy}

Fluid therapy was based on enteral nutrition given by a bottle teat or gastric tube. Continuous venous infusion was given with alprostadil, and additional fluid according to clinical needs, based on physical examination (the risk of dehydration caused by increased water loss by the radiant warmer, intensification of jaundice, poor suckling). It was not possible to compare the amount of fluid given to the patients in the control group as they were healthy, mostly breastfed newborns. The recommended amount of fluid on the first day of life should not exceed $60 \mathrm{ml} / \mathrm{kg}$, and by a slow increase on the following days, is supposed to reach the volume of $150 \mathrm{ml} / \mathrm{kg}$ by the end of the first week of life. In the study group, the mean amount of fluid given on the first day of observation (which was usually the second day of life) was $91 \mathrm{ml} / \mathrm{kg} / \mathrm{day}$, while on the second day of observation ( $3^{\text {rd }}$ to $5^{\text {th }}$ day of life) it was $128 \mathrm{ml} / \mathrm{kg} / \mathrm{day}$.

\section{Serum and urine osmolality}

The effective serum osmolality and urine osmolality values were lower in the newborns with CHD. Those differences were significant and were also maintained in the second measurement. The effective serum osmolarity did not exceed $290 \mathrm{mOsm} / \mathrm{kg}$ water. The urinary osmolarity was usually lower than the effective serum osmolarity and declined on the second day. The results of the measured parameters are presented in Table II. 
Table II. Demographic factors and clinical status presented separately for study group and term healthy newborns (control); mean (95\% Cl) or median (1Q-3Q) ${ }^{\mathrm{M}}$ Tabela II. Czynniki demograficzne i kliniczne przedstawione osobno dla grupy badanej i zdrowych noworodków (kontrola); średnia (95\% Cl) lub mediana $(1 \mathrm{Q}-3 \mathrm{Q})^{\mathrm{M}}$

\begin{tabular}{|c|c|c|c|}
\hline Parameters & $\begin{array}{l}\text { Congenital heart defect } \\
{[\mathrm{N}=10]}\end{array}$ & $\begin{array}{l}\text { Healthy neonates } \\
\qquad[N=200]\end{array}$ & $\begin{array}{l}\text { Statistical } \\
\text { significance }\end{array}$ \\
\hline Gender (M/F) & $6 / 4$ & $100 / 100$ & ns \\
\hline Mode of delivery [CS/VD] & $6 / 4$ & $100 / 100$ & ns \\
\hline Gestational age (wks) & $39(38-40)$ & $39(39-39)$ & ns \\
\hline Birth weight (g) & 3197 (2729-3665) & 3385 (3329-3442) & ns \\
\hline Apgar 5' (pts) & $9(8-10)$ & $10(10-10)$ & $<0.05$ \\
\hline Day of life & $2(2-3)$ & 3 & ns \\
\hline NTISS 1 st day (pts) & $12(8-16)$ & - & - \\
\hline NTISS $2^{\text {nd }}$ day (pts) & $13(8-17)$ & - & - \\
\hline CRP 1 st day $(\mathrm{mg} / \mathrm{dL})^{\mathrm{M}}$ & $1.13(0.4-2.5)$ & - & - \\
\hline CRP $2^{\text {nd }}$ day $(\mathrm{mg} / \mathrm{dL})^{\mathrm{M}}$ & $0.8(0.5-1.65)$ & - & - \\
\hline Creatinine $1^{\text {st }}$ day (mg/dL) & $0.90(0.73-1.07)$ & - & - \\
\hline Creatinine $2^{\text {nd }}$ day (mg/dL) & $0.66(0.50-0.83)$ & - & - \\
\hline Glucose $1^{\text {st }}$ day (mg/dL) & $85(71-98)$ & $67(65-68)$ & $<0.001$ \\
\hline Glucose $2^{\text {nd }}$ day (mg/dL) & $83(60-106)$ & - & - \\
\hline Sodium $1^{\text {st }}$ day $(\mathrm{mmol} / \mathrm{L})$ & $135(130-140)$ & $141(140-141)$ & $<0.001$ \\
\hline Sodium $2^{\text {nd }}$ day $(\mathrm{mmol} / \mathrm{L})$ & $136(133-138)$ & - & - \\
\hline Hematocrit $1^{\text {st }}$ day $(\%)$ & $49.4(44.6-54.2)$ & $50.4(49.6-51.2)$ & 0.57 \\
\hline Hematocrit $2^{\text {nd }}$ day $(\%)$ & $43.4(39.2-47.7)$ & - & - \\
\hline Osmolality $1^{\text {st }}$ day $\left(\mathrm{mOsm} / \mathrm{kg} \mathrm{H}_{2} \mathrm{O}\right)$ & $275(265-284)$ & $285(284-286)$ & $<0.001$ \\
\hline Osmolality $2^{\text {nd }}$ day $\left(\mathrm{mOsm} / \mathrm{kg} \mathrm{H} \mathrm{H}_{2} \mathrm{O}\right)$ & $276(271-282)$ & - & - \\
\hline CTproAVP $1^{\text {st }}$ day $(\mathrm{pmol} / \mathrm{L})^{\mathrm{M}}$ & $160(117-249)$ & $213(114-281)$ & 0.7 \\
\hline CTproAVP $2^{\text {nd }}$ day $(\mathrm{pmol} / \mathrm{L})^{\mathrm{M}}$ & $115(45-168)$ & - & - \\
\hline Urine osmolality 1 st day $\left(\mathrm{mOsm} / \mathrm{kg} \mathrm{H} \mathrm{H}_{2} \mathrm{O}\right)$ & $207(133-283)$ & $321(303-339)$ & $<0.01$ \\
\hline Urine osmolality $2^{\text {nd }}$ day $\left(\mathrm{mOsm} / \mathrm{kg} \mathrm{H}_{2} \mathrm{O}\right)$ & $156(90-222)$ & - & - \\
\hline Fluids $1^{\text {st }}$ day $[\mathrm{ml} / \mathrm{kg} /$ day] & $91(73-109)$ & - & - \\
\hline Fluids $2^{\text {nd }}$ day [ml/kg/day] & $128(105-150)$ & - & - \\
\hline
\end{tabular}

Apgar $5^{\prime}-$ Agar score at the $5^{\text {th }}$ minute of life, CRP - C-reactive protein, CS - caesarean section, F - female, g - grams, M - male, ns - not significant, NTISS - Neonatal Therapeutic Intervention Scoring System, pts - points, VD - vaginal delivery, wks - weeks

\section{Serum CTproAVP concentrations}

There were differences in the CTproAVP concentrations, though not statistically significant, between the study and control populations, with lower values in the CHD group. Moreover, the serum concentration of CTproAVP was stable during the second day, and only in two newborns the results of the CTproAVP measurements were over the reference values established in the controls $\left(5^{\text {th }}-95^{\text {th }}\right.$ percentile: $305-1665 \mathrm{pg} / \mathrm{ml})$.

The cardiologic evaluation did not reveal any symptoms of cardiovascular distress in the observational period, with blood pressure within the normal range for age and sufficient diuresis.

\section{DISCUSSION}

The results of our observations made us realize that the protocol, considered restrictive, did not in fact result in the stimulation of CTproAVP. Unexpectedly, the CTproAVP concentrations, effective serum osmolality and urine osmolality in the study group were lower in comparison to routinely treated healthy newborns. The amount of fluid given to our patients was kept between the range recommended on the particular day of life [12]. Nonetheless, taking into consideration the underlying pathologies, we aimed for moderate hydration and not to overload the patients. Based on the serum and urine osmolality, the results were not par- 
allel to our assumptions. There was no evidence for cardiovascular insufficiency, including pulmonary congestion, or fluid overload in ECHO imaging. The physicians who prescribed the nutrition and medication made some modifications in fluid intake based on physical examination and the current basic laboratory results. They did not use ECHO to evaluate the circulatory status, but that was done by consulting a cardiologist on an everyday basis (usually once, if the clinical condition did not require otherwise). The nursing staff was allowed to give an additional small amount (a few milliliters) of mother's milk or formula if the newborn was showing any symptoms of hunger. As all the study patients were born at term, they should be fed on demand, if they were staying with their mothers [12].

In conclusion, the amount of fluid the test group of newborns received, which - based on the osmolality and CTproAVP measurements - resulted in greater hydration than in the healthy newborns constituting the control group. On the other hand, those healthy newborns were mostly only breastfed, with no additional fluids. Those controls were kept in regular neonatal beds with no additional heating. No medications were given to them, nor was any (only basic care) medical procedure performed. They even presented jaundice, which was regarded as a physiological symptom and effected only by more dedicated breastfeeding. The knowledge that our patients with CHD were at risk of being overloaded with fluids (they did not, however, show any clinical symptom of overload) is not reassuring for us and raises the important question about the ward clinical management.

It also raises some questions about the possible long-term effects, including the response of the body to surgery and stress. It is tempting to reduce the amount of fluid by controlling the studied parameters, but one may ask how sure we are that the indicated values of copeptin should be taken into account when making clinical decisions.

There are evident lower values of sodium and hematocrit than in the term healthy population. That is why low effective serum osmolality and low urine osmolality seem to be natural consequences [13]. CTproAVP is, on the other hand, a relatively new marker, but being a surrogate for AVP informs about one of the basic and important regulatory mechanisms of blood volume. Worth noting are other factors affecting its value like stress, hypoxia, sepsis or circulatory insufficiency.

CTproAVP assessed in adolescents was elevated in primary hypertension and correlated not only with higher values of systolic and diastolic pressure but also with markers of metabolic status such as body mass, body mass index or triglycerides [14]. Further research was done by Nickel et al. [10], who compare the copeptin concentration with other markers of cardiovascular status and renal efficiency (creatinine, glomerular filtration rate - GFR) in adults suffering from pulmonary arterial hypertension (PAH). The authors were able to confirm a correlation between CTproAVP and the parameters of disease severity, but not with hemodynamics. Nevertheless, the copeptin levels decreased when PAH treatment was initiated. They suggested an interesting explanation for elevated CTproAVP, as a result of neurohormonal stimulation, which also caused volume overload. In such a situation, copeptin would not be responsible, at least not alone or to a significant extent, for volume overload and symptoms of right heart strain. Both papers suggest the existence of other factors that play an important role in the body's regulatory mechanisms.

Another possible role of copeptin - as a marker of endogenous stress - has been analyzed mainly in connection with sudden cardiac episodes, like acute myocardial infarction (AMI). This entity is considered to be very painful, but the response to pain stimulus is individually different, and this can be evaluated by measuring CTproAVP - one of the main regulating factors of the hypothalamic-pituitary-adrenal axis $[7,13,15]$. Reichlin et al. [16] described the pattern of CTproAVP release in AMI patients, pointing to a very fast increase in marker concentration parallel to the occurrence of chest pain. These data were used in a project by Chenevier-Gobeaux et al. [17], who proved that CTproAVP could be an important element in a panel of markers used to exclude AMI. Dedic et al. [18] sought a correlation between copeptin concentration and the clinical situation of increased risk for AMI: acute coronary symptoms (ACS) and coronary artery disease (CAD). Importantly, all the ACS patients (diagnosed finally with myocardial infarction or unstable angina pectoris) presented an elevated CTproAVP concentration, while patients with CAD had a higher copeptin level only in symptomatic cases (ACS). These findings also support the role of copeptin as a stress marker. Undoubtedly, copeptin together with AVP and cortisol are secreted in response to life-threatening events, and AMI is one of them [18]. There is, however, a possibility that the basic pathologic mechanism of copeptin release is connected to the stimulation of baroreceptors in response to cardiac damage, and subsequent underfilling of heart ventricles [19]. Degenerative aortic stenosis, another damage condition, according to the authors correlated with a rise in the CTproAVP concentration [20]. It is difficult to compare these findings with our results as the diagnosed heart defects did not cause any cardiac damage at the time of the observation. Our patents did not present any heart failure nor any signs of cardiovascular insufficiency either, which is the other important clinical condition widely described in connection to elevated serum copeptin $[19,21]$. Stress 
as a releasing factor of copeptin was also mentioned by Katan et al. [22], who described patients with ischemic shock and a higher copeptin level.

Comparing the CTproAVP values in the above-mentioned cases with the results we obtained, there was an evidently higher concentration in the newborns than in adolescents or adults. The presented reference range of CTproAVP $\left(5^{\text {th }}-95^{\text {th }}\right.$ percentile $)$ was quite high indeed in comparison to the ranges observed in adult cohorts. Notwithstanding, other authors also reported values of CTproAVP in infants significantly different from those measured in older patients $[23,24,25]$. The pathophysiological explanation of the difference is not clear as not all the factors influencing the CTproAVP concentration have been described and not in a complete way. This may suggest that direct comparison of these two populations is not easy and not all experiences gained from adult studies can be extrapolated to newborns.

The search for medical articles dealing with the cardiosurgical aspect in the pediatric population was not very fruitful. Perez-Navero et al. [23] analyzed a group of pediatric patients undergoing cardiac surgery and looked for biomarkers of low cardiac output syndrome (LCOS). Even though copeptin was not indicated as a key prognostic parameter, still, it was noticed that initially (just after the surgery) the newborns who did not develop an inadequate heart minute volume were characterized by higher CTproAVP values, and the CTproAVP concentrations decreased in subsequent evaluations. Other patients who presented LCOS had an increased copeptin level only at one point in time, two hours after surgery. It is not clear if the initial rise in CTproAVP in the non-LCOS group was caused by stress or lower hydration and higher osmolality.

A recent Polish study regarding community-acquired pneumonia in children showed that CTproAVP was significantly higher in the group of ill children in comparison to healthy controls [26]. A relation between the stage of severity and CTproAVP concentration could not, however, be found. Regarding respiratory support applied in some of our patients, we may suspect that the fact of respiratory distress increased the CTproAVP values, but still it cannot be an explanation when compared to the CTproAVP reference ranges in the healthy controls.

When analyzing factors of the possible influence on CTproAVP, renal functioning and sodium concentration also have to be considered. It is known that the CTproAVP level increases if there is a high sodium concentration and serum osmolality, and low volemia
[4]. On the contrary, a low sodium concentration and at least a sufficient blood volume correlate with a relatively low copeptin level. These were the findings in our study population. It should be noted that a low level of stress did not cause any additional CTproAVP release. Nonetheless, it would be of interest to continue our observation and check the CTproAVP concentration after cardiac surgery, with the possible input of perioperative stress. In such a case, a nonosmotic (but due to pain and anxiety) cause of AVP and CTproAVP release could be observed [27]. Maintaining an optimal fluid balance would be crucial, but the administration of hypotonic fluids is not justified in this situation.

In summary, back to our study population, we looked at the possible factors of copeptin release and could exclude cardiovascular insufficiency (echocardiography monitoring), hypoxia (saturations in normal ranges), pain (no symptoms) and only in three patients there were moderate symptoms of intrauterine infection (negative blood cultures). We may speculate that the lower copeptin concentration in comparison to the healthy newborns was mostly shaped by a lack of stress factors and sufficient hydration, on the border of overhydration when considering sodium serum concentrations.

We recognize some indisputable limitations of our work, mainly the small size of the study group and the heterogeneity of the study population. Every case of complicated CHD is literally individual, therefore comparison between them is difficult. Additionally, other factors such as respiratory support or infections may affect volume sensing and release of the hormones. Due to the small size of the studied group, we cannot draw any strong conclusions and we consider the results as preliminary data. Nevertheless, there is a potential possibility to lower the fluid input in newborns with CHD under close monitoring of traditional and novel markers of blood volume. Longer observations and less liberal hydration in the perioperative period could potentially provide reliable information on optimal fluid management in this group of patients and elucidate the role of CTproAVP in blood volume control.

\section{Acknowledgement}

This study was supported by a grant from Medical University of Silesia (KNW - 2-K20/N/6/N)

\section{Conflict of interests}

The authors declare that there is no conflict of interests regarding the publication of this paper. 


\section{Author's contribution}

Study design - A. Tarko, I. Maruniak-Chudek

Data collection - A. Tarko, A. Suchojad, J. Kordyś, S. Simonova

Data interpretation - A. Tarko, A. Suchojad, I. Maruniak-Chudek

Statistical analysis - I. Maruniak-Chudek

Manuscript preparation - A. Tarko, A. Suchojad, I. Maruniak-Chudek

Literature research - J. Kordyśs, S. Simonova

\section{REFERENCES}

1. Morgenthaler N.G. Copeptin: a biomarker of cardiovascular and rena function. Congest. Heart Fail. 2010; 16(suppl 1): S37-44, doi: 10.1111/j.17517133.2010.00177.x

2. Katan M., Christ-Crain M. The stress hormone copeptin: a new prognostic biomarker in acute illness. Swiss Med. Wkly 2010; 140: w13101, doi 10.4414/smw.2010.13101

3. Holwerda D.A. A glycopeptide from the posterior lobe of pig pituitaries. I. Isolation and characterization. Eur. J. Biochem. 1972; 28(3): 334-339, doi: 10.1111/j.1432-1033.1972.tb01918.x

4. Struck J., Morgenthaler N.G., Bergmann A. Copeptin, a stable peptide derived from the vasopressin precursor, is elevated in serum of sepsis patients. Peptides 2005; 26(12): 2500-2504, doi: 10.1016/j.peptides.2005.04.019.

5. Stoiser B., Mörtl D., Hülsmann M., Berger R., Struck J., Morgenthaler N.G., Bergmann A., Pacher R. Copeptin, a fragment of the vasopressin precursor, as a anovel predictor of outcome in heart failure. Eur. J. Clin. Invest. 2006; 36(11): 771-778, doi: 10.1111/j.1365-2362.2006.01724.x.

6. Morgenthaler N.G., Müller B., Struck J., Bergmann A., Redl H., Christ-Crain M. Copeptin, a stable peptide of the arginine vasopressin precursor, is elevated in hemorrhagic and septic shock. Shock 2007; 28(2): 219-226, doi 10.1097/SHK.0b013e318033e5da.

7. Katan M., Morgenthaler N.G., Widmer I., Puder J.J., König C., Müller B., Christ-Crain M. Copeptin, a stable peptide derived from the vasopressin precursor, correlates with the individual stress level. Neur. Endocrinol. Lett. 2008; 29(3): 341-346.

8. Lipinski M.J., Escárcega R.O., D’Ascenzo F., Magalhães M.A., Baker N.C., Torguson R. et al. A systematic review and collaborative meta-analysis to determine the incremental value of copeptin for rapid rule-out of acute myocardial infarction. Am. J. Cardiol. 2014; 113(9): 1581-1591, doi: 10.1016/j.amjcard.2014.01.436

9. Alehagen U., Dahlström U., Rehfeld J.F., Goetze J.P. Association of copeptin and N-terminal proBNP concentrations with risk of cardiovascular death in older patients with symptoms of heart failure. JAMA 2011;305(20): 2088-2095, doi: 10.1001/jama.2011.666.

10. Nickel N.P., Lichtinghagen R., Golpon H., Olsson K.M., Brand K., Welte T., Hoeper M.M. Circulating levels of copeptin predict outcome in patients with pulmonary arterial hypertension. Respir. Res. 2013; 14(1): 130, doi: 10.1186/1465-9921-14-130.

11. Neuhold S., Huelsmann M., Strunk G., Stoiser B., Struck J., Morgenthale N.G. et al. Comparison of copeptin, B-type natriuretic peptide, and amino-terminal pro-B-type natriuretic peptide in patients with chronic heart failure: prediction of death at different stages of the disease. J. Am. Coll. Cardiol. 2008; 52(4): 266-272, doi: 10.1016/j.jacc.2008.03.050.

12. Furman L., Schanler R.J. Nutrition. [In:] Gleason Ch.A., Devaskar Sh.U. Avery's diseases of the newborn. $9^{\text {th }}$ Ed. Elsevier Saunders. Philadelphia 2012; pp. $937-959$

13. Katan M., Müller B., Christ-Crain M. Copeptin: a new and promising diagnostic and prognostic marker. Crit. Care 2008; 12(2): 117, doi $10.1186 / \mathrm{cc} 6799$.

14. Tenderenda-Banasiuk E., Wasilewska A., Filonowicz R., Jakubowska U, Waszkiewicz-Stojda M. Serum copeptin levels in adolescents with primary hypertension. Pediatr. Nephrol. 2014; 29(3): 423-429, doi: 10.1007/s00467$013-2683-5$

15. Itoi K., Jiang Y.Q., Iwasaki Y., Watson S.J. Regulatory mechanisms of corticotropin-releasing hormone and vasopressin gene expression in the hypothalamus. J. Neuroendocrinol. 2004; 16(4): 348-355, doi: 10.1111/j.09538194.2004.01172.x.

16. Reichlin T., Hochholzer W., Stelzig C., Laule K., Freidank H., Morgenthaler N.G. et al. Incremental value of copeptin for rapid rule out of acute myocardial infarction. J. Am. Coll. Cardiol. 2009; 54(1): 60-68, doi: 10.1016/j.jacc.2009.01.076

17. Chenevier-Gobeaux C., Freund Y., Claessens Y.E., Guérin S., Bonnet P., Doumenc B. et al. Copeptin for rapid rule out of acute myocardial infarction in emergency department. Int. J. Cardiol. 2013; 166(1): 198-204, doi: 10.1016/j.ijcard.2011.10.098

18. Dedic A., ten Kate G.J., Rood P.P., Galema T.W., Ouhlous M., Moelker A. et al. Copeptin in acute chest pain: identification of acute coronary syndrome and obstructive coronary artery disease on coronary CT angiography. Emerg. Med. J. 2013; 30(11): 910-913, doi: 10.1136/emermed-2012-201596.

19. Griebel G., Stemmelin J., Gal C.S., Soubrié P. Non-peptide vasopressin $\mathrm{V} 1 \mathrm{~b}$ receptor antagonists as potential drugs for the treatment of stress-related disorders. Curr. Pharm. Des. 2005; 11(12): 1549-1559, doi: 10.2174/1381612053764797.

20. Mizia-Stec K., Lasota B., Mizia M., Chmiel A., Adamczyk T., Chudek J., Gasior Z. Copeptin constitutes a novel biomarker of degenerative aortic stenosis. Heart Vessels 2013; 28(5): 613-619, doi: 10.1007/s00380-012-0293-y. 21. Goldsmith S.R. Congestive heart failure: potential role of arginine vasopressin antagonists in the therapy of heart failure. Congest. Heart Fail. 2002; 8(5): 251-256, doi: 10.1111/j.1527-5299.2002.01158.x.

22. Katan M., Fluri F., Morgenthaler N.G., Schuetz P., Zweifel Ch., Bingisser R. et al. Copeptin: a novel, independent prognostic marker in patients with ischemic stroke. Ann. Neurol. 2009; 66(6): 799-808, doi: 10.1002/ana.21783.

23. Pérez-Navero J.L., de la Torre-Aguilar M.J., de la Rosa I.I., Gil-Campos M., Gómez-Guzmán E., Merino-Cejas C. et al. Cardiac Biomarkers of Low Cardiac Output Syndrome in the Postoperative Period After Congenital Heart Disease Surgery in Children. Rev. Esp. Cardiol. 2017; 70(4): 267-274, doi: 10.1016/j.rec.2016.09.011.

24. Rouatbi H., Zigabe S., Gkiougki E., Vranken L., Van Linthout C., Seghaye M.C. Biomarkers of neonatal stress assessment: A prospective study. Early Hum. Dev. 2019; 137: 104826, doi: 10.1016/j.earlhumdev.2019.104826.

25. Kasser S., Hartley C., Rickenbacher H., Klarer N., Depoorter A., Datta A.N. et al. Birth experience in newborn infants is associated with changes in nociceptive sensitivity. Sci. Rep. 2019; 9(1): 4117, doi: 10.1038/s41598-01940650-2.

26. Wrotek A., Jackowska T., Pawlik K. Sodium and copeptin levels in children with community acquired pneumonia. Adv. Exp. Med. Biol. 2015; 835: 31-36, doi: 10.1007/5584_2014_41.

27. Hoorn E.J., Geary D., Robb M., Halperin M.L., Bohn D. Acute hyponatremia related to intravenous fluid administration in hospitalized children: an observational study. Pediatrics 2004; 113(5): 1279-1284, doi: 10.1542/peds.113.5.1279 